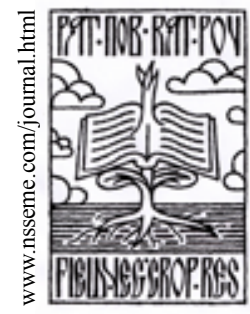

\title{
Association between Seed Yield and Some Morphological Characteristics in Sunflower
}

\author{
Milan Jocković • Radovan Marinković • Ana Marjanović-Jeromela • \\ Velimir Radić • Petar Čanak • Nada Hladni
}

\author{
received: 17 November 2011, accepted: 25 January 2012. \\ (C) 2012 IFVC \\ doi:10.5937/ratpov49-1205
}

\begin{abstract}
Summary: Objective of this study was to determine the divergence and association between seed yield and three morphological characteristics that are very important in sunflower breeding (plant height, head diameter and days to flowering) in order to identify the most valuable trait for seed yield improvement. Forty new hybrid combinations were evaluated. Cluster analysis was used to determine genetic diversity in new hybrid combinations by classifying genotypes based on average values of the studied characteristics. Genotypes were classified into three homogenous groups and six individuals. Pearson's correlation coefficients were used to examine association between the studied characteristics, among which days to flowering showed negative correlation while plant height and head diameter showed positive correlation with seed yield, on both genotypic and phenotypic levels. Our study showed that there is genetic variability among new hybrids and bearing in mind that hybrids should be grown in different agro-ecological environments, our attention should be focused on developing inbred lines with lower stem resistant to lodging, larger head diameter and earlier flowering.
\end{abstract}

Key words: cluster analysis, correlation coefficients, days to flowering, head diameter, morphological characteristics, plant height, seed yield, sunflower

\section{Introduction}

Sunflower is an important oilseed and food crop worldwide. It is the fifth largest edible oilseed crop grown on 22.9 million hectares (Seiler \& Jan 2010). Being a source of tocopherols and phytosterols, sunflower oil has positive effects on human health (Gotar et al. 2008), cancer prevention (Bramley et al. 2000) and lowers blood cholesterol levels (Patel \& Thompson 2006).

Genetic divergence is very important to plant breeders since the greater divergence between parents the greater the chances for obtaining superior $F_{1}$ plants. Cluster analysis is a collection of statistical methods that determines the phenotypic divergence in a number of characteristics. This analysis groups similar and separates different genotypes. Cluster analysis was already used for investigation of genetic divergence of sunflower and genotype classification (Anuradha et al. 2004, Reddy et al. 2004, Loganathan et al. 2006, Mahalaksmi et al. 2006, Binodh et al. 2007).

M. Jocković* • R. Marinković • A. Marjanović-Jeromela • V. Radić • P. Čanak • N. Hladni

Institute of Field and Vegetable Crops, Maksima Gorkog 30, 21000

Novi Sad, Serbia

e-mail:milan.jockovic@ifvcns.ns.ac.rs
The main objectives in sunflower breeding are increased seed yield and oil content, but achieving these goals involves the breeding of other traits that are related directly or indirectly. It is very important to measure the association between yield traits to determine the component on which selection can be based for yield improvement. Genotypic and phenotypic correlation coefficients reveal the extent of association between different traits. Many researchers have used correlations to examine the relationships among yield components in sunflowers (Kaya et al. 2003, Joksimovic et al. 2004, Hladni et al. 2004, Dušanić et al. 2004). Days to flowering, plant height and head diameter are important characteristics affecting the yield.

Days to flowering (DTF) is important feature in sunflower breeding because the hybrid productivity depends on its phenological suitability for certain production region.

One of the recent objectives in sunflower breeding is improved harvest index and lodging resistance via reduced plant height (Marinković \& Dozet 1997).

Acknowledgement: This study is a part of research on the project TR31025 "Development of new varieties and production technology improvement of oil crops for different purposes" financed by the Ministry of Science and Education of the Republic of Serbia. 
In regions with strong winds and heavy precipitation higher genotypes are exposed to lodging, which reduce yield and seed quality (Marinković et al. 2002). In order to have a hybrid which can be grown in different agro-ecological environments optimum plant height should be between $150-170 \mathrm{~cm}$. By developing hybrids $120-150 \mathrm{~cm}$ in height, it is possible to improve resistance to lodging and make harvesting easier (Schneiter et al. 1988).

Special attention in sunflower breeding should be given to the characteristics of the head (Mijić et al. 2005). Optimum head diameter should be 20-25 cm (Škorić et al. 1989). Head diameter has direct and indirect influence on seed yield per plant via number of flowers and filled seeds per head (Tahir et al. 2002, Hladni 2010).

The objective of this study was to determine the divergence and association between seed yield and three morphological characteristics that are very important in sunflower breeding (plant height, head diameter and days to flowering) in order to identify the most valuable trait for seed yield improvement. Such approach will simplify the selection of genotypes with desired characteristics and will result with more effective sunflower breeding program.

\section{Materials and Methods}

Material used in this study consisted of 40 new hybrid combinations developed at the Institute of Field and Vegetable Crops in Novi Sad, Serbia.
The field experiment was laid out in 2010 in a randomized complete block design with three replicates at the experimental field Rimski Šancevi of the Institute of Field and Vegetable Crops in Novi Sad. Basic plots were $10 \mathrm{~m}^{2}$, with four $3.6 \mathrm{~m}$ long rows and $70 \times 30 \mathrm{~cm}$ plant spacing. The data were recorded on 20 plants from middle rows (in each replicate) and harvest was performed manually. The days to flowering (DTF) is the number of days from emergence to $50 \%$ flowering (R5.5 stage according to Schneiter \& Miller 1981). Plant height and head diameter were measured at the stage of physiological maturity. Seed yield per plant was recorded in laboratory. Cluster analysis was performed to assign genotypes into qualitative homogenous groups based on average values of the studied characteristics applying Statistica for Windows v.10 (StatSoft, USA). Interrelationships between the studied characteristics were determined by calculating Pearson's correlation coefficients. The significance of coefficients was determined by applying t-test, according to Hadživuković (1973).

\section{Results and Discussion}

The genotypes were classified in three main groups using cluster analysis (Fig. 1). Cluster analysis is of practical use in plant breeding because it indicates the extent of genetic diversity. It is useful analysis for identification of genotypes with desirable traits. The first group is divided

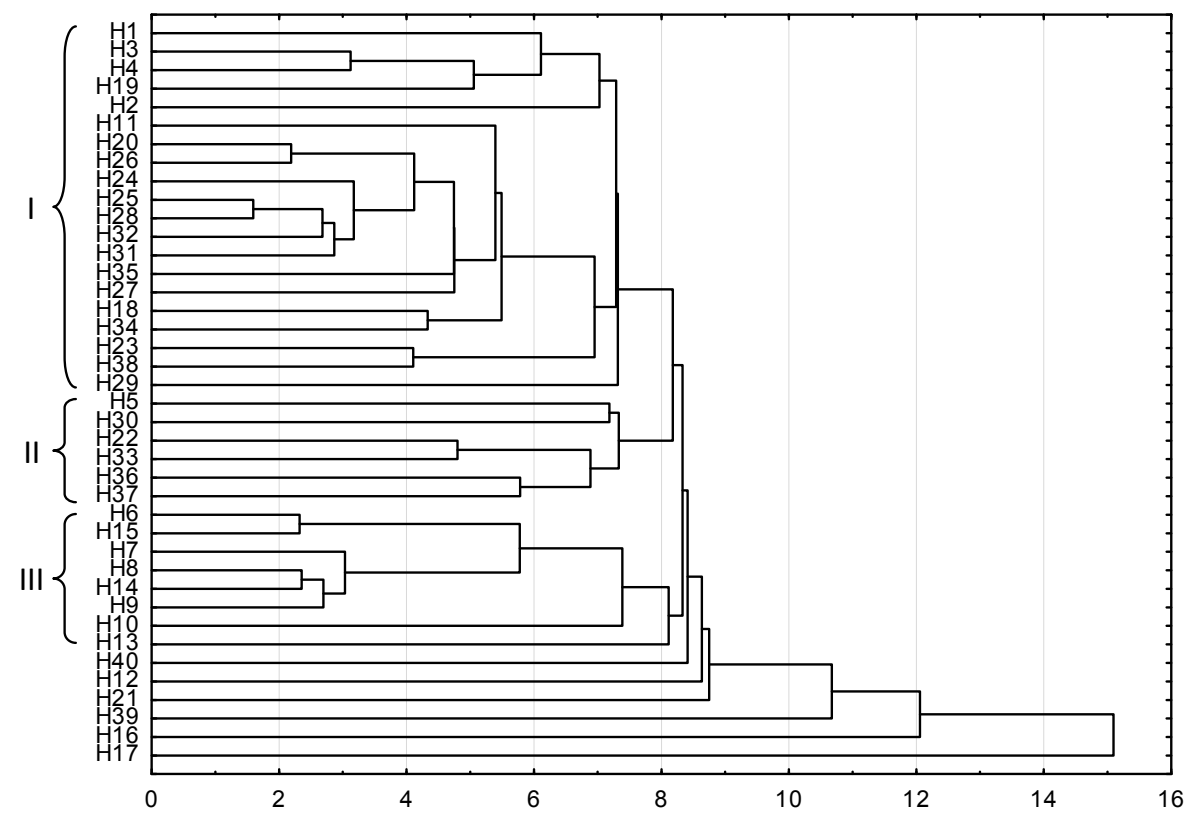

Fig. 1. Cluster analysis of 40 sunflower hybrid combinations

Graf. 1. Klaster analiza 40 hibridnih kombinacija suncokreta 
into two subgroups. The first subgroup consists of genotypes $\mathrm{H} 1, \mathrm{H} 3, \mathrm{H} 4, \mathrm{H} 19$ and $\mathrm{H} 2$, while in the second subgroup there are genotypes $\mathrm{H} 11$, $\mathrm{H} 20, \mathrm{H} 26, \mathrm{H} 24, \mathrm{H} 25, \mathrm{H} 28, \mathrm{H} 32, \mathrm{H} 31, \mathrm{H} 35$, $\mathrm{H} 27, \mathrm{H} 18, \mathrm{H} 34, \mathrm{H} 23, \mathrm{H} 38$ and $\mathrm{H} 29$. The second group is comprised of genotypes $\mathrm{H} 5, \mathrm{H} 30, \mathrm{H} 22$, $\mathrm{H} 33, \mathrm{H} 36$ and H37. As shown in Table 1 these genotypes are characterized by plant height below $200 \mathrm{~cm}$. Genotypes that are in the third group (H6, H15, H7, H8, H14, H9, H10 and H13) are characterized by high values of plant height and seed yield. Figure 1 shows that six genotypes were not grouped but are separated individually. Among them the most prominent are genotypes

Table 1. Average values of the studied morphological characteristics in sunflower Tabela 1. Srednje vrednosti ispitivanih morfoloskih svojstava suncokreta

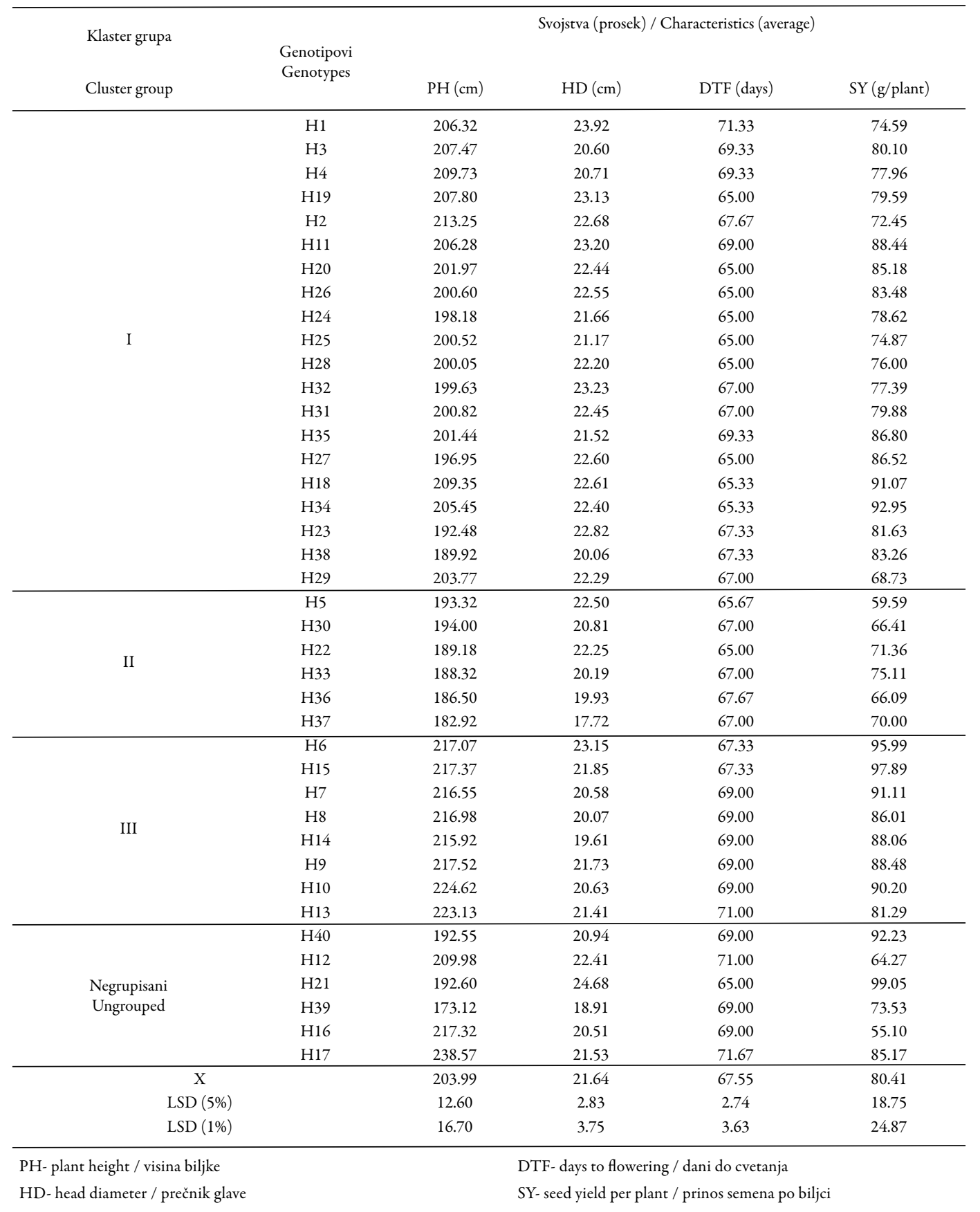


Table 2. Genotypic ( $\mathrm{rg}$ ) and phenotypic (rp) correlation coefficients of the studied morphological characteristics on seed yield of 40 sunflower hybrid combinations

Tabela 2. Genotipski (rg) i fenotipski (rp) koeficijenti korelacije izučavanih morfoloških osobina na prinos semena 40 hibridnih kombinacija suncokreta

\begin{tabular}{cccccc}
\hline $\begin{array}{c}\text { Svojstva } \\
\text { Characteristics }\end{array}$ & $\mathrm{r}$ & PH & HD & DTF & SY \\
\hline PH & rg & 1 & 0.17 & $0.54^{* *}$ & $0.40^{*}$ \\
& rp & 1 & 0.18 & $0.37^{*}$ & 0.24 \\
& & & & 0.13 \\
HD & rg & & 1 & -0.06 & 0.30 \\
& rp & & 1 & -0.02 & -0.07 \\
DTF & rg & & & & -0.01 \\
\hline
\end{tabular}

${ }^{*} \mathrm{p}<0.05,{ }^{* *} \mathrm{p}<0.01$

PH- plant height / visina biljke

HD- head diameter / prečnik glave

H21 with the highest seed yield, $\mathrm{H} 17$ with the highest plants and H16 which had the lowest seed yield (Tab. 1).

Correlation coefficients are useful because we can determine the component character on which selection can be based, thus improving seed yield. Plant height showed significant and positive correlation with seed yield at genotypic level, while positive but non significant correlation at phenotypic level. These results are contrary to those of Arshad et al. (2007) who found that association between plant height and seed yield was negative at both levels. Plant height had highly significant and positive correlation with days to flowering at genotypic level, while significant at phenotypic level (Tab. 2). The more extended the number of days to flowering the plant will have more time to grow, as when flowering begins nutrients are transferred to head. Plant height was positively correlated with head diameter at both levels, while Tahir et al. (2002) found positive and highly significant correlation between plant height and head diameter.

Head diameter had positive but non significant correlation with seed yield, while negative correlation with days to flowering, at both levels (Tab. 2). Yasin \& Singh (2010) and Behradfar et al. (2009) also found positive but highly significant correlation between head diameter and seed yield. Head diameter affects the number of flowers and seeds per head. Larger heads will produce more number of seeds leading to higher yield.

Days to flowering showed negative but non significant correlation with seed yield (Tab. 2). Our results are in agreement with findings of Kaya et al. (2009) and Arshad et al. (2007) who
DTF- days to flowering / dani do cvetanja

SY-seed yield per plant / prinos semena po biljci

also found negative correlation between these two characteristics. This can be explained by the fact that as soon as flower initiation begins head will have more time to accumulate nutrients and grow until the end of physiological maturity. Development of inbred lines with earlier flowering period would be important because such heads will have more time for seed filling.

Based on the results from this study, plant height showed the highest positive genotypic effect on seed yield. The selection of hybrids that will be grown in different agro-ecological conditions should be based on all investigated traits. Cluster analysis is useful for identification of genotypes that have high values for seed yield and head diameter, but lower values for plant height and earlier flowering period. Considering the previous, the most promising hybrids are $\mathrm{H} 21$ and $\mathrm{H} 34$, but we should not left out hybrids $\mathrm{H} 6$ and $\mathrm{H} 15$ which had high seed yield but due to high plant they are not recommended for areas with strong winds and heavy rainfall.

\section{Conclusions}

The sunflower hybrids analyzed in this study were genetically divergent. Correlation coefficients showed that all investigated traits have important role in the formation of seed yield. Bearing in mind that hybrids should be grown in different agro-ecological environments, our attention should be focused on developing inbred lines with lower stem resistant to lodging, larger head diameter and earlier flowering to extend seed filling period. The cluster analysis enables selection of genotypes with desirable traits. 


\section{References}

Anuradha N, Ramakumar PV, Vishnuvardhan RA, Durga RCHV (2004): Genetic Divergence in Sunflower (H.annuus L.). Andhra Agric. J. 51: 39-43

Arshad M, Ilyas MK, Khan MA (2007): Genetic divergence and path coefficient analysis for seed yield traits in sunflower (Helianthus annuus L.) hybrids. Pak. J. Bot. 39: 2009-2015

Behradfar A, Gorttapeh AH, Zardashty MR, Talat F (2009): Evaluation Correlated Traits for Seed and Oil Yield in Sunflower (Helianthus annuus L.). Through Path Analysis in under Condition Relay Cropping. Res. J. Biol. Sci. 4: 82-85

Binodh AK, Manivannan N, Varman PV (2006): Cluster analysis of yield traits in sunflower (Helianthus annuus L.). Madras Agric. J. 94: 27-31

Bramley PM, Elmafda I, Kafatos A, Kelly FJ, Manios Y, Roxborough HE, Schuch W, Sheehy PJA, Wagner KH (2000): Vitamin E. J. Sci. Food Agric. 80: 913-938

Dušanić N, Miklič V, Joksimović J, Atlagić J, Crnobarac J (2004): Path coefficient analysis of some yield components of sunflower. Proceedings of the 16th International Sunflower Conference, August 29-September 2, Fargo, ND, US, 531-537

Farhatullah FEA, Khalil IH (2006): Path analysis of the coefficients of sunflower (Helianthus annus L.). Int. J. Agri. Biol. 8: 621-625

Gotar AA, Berger M, Labalette F, Centis S, Dayde J, Calmon A (2008): Estimation of breeding potential for tocopherols and phytosterols in sunflower. Proceedings of the 17 th International Sunflower Conference, June 8-12, Cordoba, Spain, 555-559

Hadživuković S (1973): Statistički metodi. Radivoj Ćirpanov, Novi Sad

Hladni N, Škorić D, Balalić M K, Ivanović M, Sakač Z, Jovanović $\mathrm{D}$ (2004). Correlation of yield components and seed yield per plant in sunflower $(H$. annuus L.). Proceedings of the 16 th International Sunflower Conference, August 29-September 2, Fargo, ND, US, 492-495

Hladni N (2010): Geni i prinos suncokreta (monografija). Zadužbina Andrejević (posebna izdanja), Beograd

Joksimović J, Atlagić J, Jovanović D, Marinković R, Dušanić N, Miklič V (2004): Path

coefficient analysis of some head and seed components in sunflower. Proceedings of the 16th International Sunflower Conference, August 29-September 2, Fargo, ND, US, 525-530

Kaya Y, Evci G, Pekcan V, Gucer T (2003): The determination of the contribution on important yield components to seed and oil yield in sunflower. Proceeding of 5th Turkish Field Crops Congress, October 1317, Diyarbakir, Turkey, 120-125

Kaya Y, Evci G, Durak S, Pekcan V, Gucer T (2009): Yield components affecting seed yield and their relationships in sunflower (Helianthus annuus L.). Pak. J. Bot. 41: 2261-2269

Loganathan P, Gopalan A, Manivannan N (2006): Genetic divergence in sunflower (Helianthits annuus $\mathrm{L}$ ). Research on Crops 7: 198-201

Mahalakshmi P, Vidhyavathi R, Manivannan N, Muralidharan V (2006): Genetic Divergence in sunflower. Agric. Sci. Digest 26: $138-140$

Marinković R, Dozet B (1997): Genetička istraživanja u svetu u funkciji oplemenjivanja. Zbornik radova Naučnog instituta za ratarstvo i povrtarstvo, Novi Sad 29: 569-592

Marinković R, Škorić D, Jovanović D (2002): Efekat heterozisa za visinu biljke i prečnik glave kod suncokreta (Helianthus annuus L.). Zbornik radova instituta za ratarstvo i povrtarstvo, Novi Sad. Sveska 36, 169-177.

Mijić A, Krizmanić M, Liović I, Bilandžić M, Zdunić Z, Kozumplik V (2005): Procjena kombinacijskih sposobnosti i genetskih učinaka za visinu biljke i promjer glave suncokreta. Poljoprivreda 11: 18-23

Patel MD, Thompson PD (2006): Phytosterols and vascular disease. Atherosclerosis 186: 12-19

Reddy RS, Dangi KS, Reddy AV, Kumar SS (2004): Genetic divergence in newly developed sunflower (Helianthus annuus L.). J. Oilseeds Res. 21: 166-167

Schneiter AA, Curadar B, Zaffdroni G, Maid H (1988): Agronomic evaluation of semi dwarf sunflower. Proceedings of the 12th International Sunflower Conference, July 25-29, Novi Sad, Yugoslavia, 406-408

Schneiter AA, Miller JF (1981): Description of sunflower growth stages. Crop Sci. 21: 901-903

Seiler G, Jan CC (2010): Genetics, genomics and breeding of sunflower. Science publishers, Enfield, New Hampshire

Škorić D, Vrebalov T, Ćupina T, Turkulov J, Marinković R, Maširević S, Atlagić J, Tadić L, Sekulić R, Stanojević D, Kovačević M, Jančić V, Sakač Z (1989): Suncokret (monografija), Nolit, Beograd

Tahir MHN, Sadaqat HA, Bashir S (2002): Correlation and path coefficient analysis of morphological traits in sunflower (Helianthus annuus L.) populations. Int. J. Agri. Biol. 4: 341-343

Yasin AB, Singh S (2010): Correlation and path coefficient analysis in sunflower. J. Plant. Breed. Crop Sci. 2: 129-133

\title{
Povezanost između prinosa semena i nekih morfoloških svojstava suncokreta
}

\author{
Milan Jocković • Radovan Marinković • Ana Marjanović-Jeromela • \\ Velimir Radić • Petar Čanak • Nada Hladni
}

Izvod: Cilj ovog rada je bio da se utvrdi divergentnost i povezanost između prinosa semena i tri morfološka svojstva koja su veoma važna u oplemenjivanju suncokreta (visina biljke, prečnik glave i broj dana do cvetanja) kako bi se identifikovalo najznačajnije svojstvo. Četrdeset novih hibridnih kombinacija je ocenjeno u ovom istraživanju. Klaster analiza je korištena za određivanje genotipske divergentnosti u novim hibridnim kombinacijama klasifikacijom genotipova na osnovu srednjih vrednosti ispitivanih svojstava. Genotipovi su klasifikovani u tri homogene grupe i šest pojedinačnih. $\mathrm{Za}$ istraživanje povezanosti ispitivanih svojstava korišteni su Pirsonovi koeficijenti korelacije. Između ispitivanih svojstava, dani do cvetanja su pokazali negativnu korelaciju, dok su visina biljke i prečnik glave pokazali pozitivnu korelaciju sa prinosom semena, na genotipskom i fenotipskom nivou. Naša studija je pokazala da između novih hibrida postoji genetička varijabilnost a imajući u vidu da hibridi treba da se gaje u različitim agro-ekološkim uslovima naša pažnja treba da se usmeri na stvaranje inbred linija niže stabljike otporne na poleganje, većeg prečnika glave i ranijeg cvetanja. Ključne reči: dana do cvetanja, klaster analiza, koeficijenti korelacije, morfološka svojstva, prečnik glave, prinos semena, suncokret, visina biljke 